\title{
Shifting Global Citizenship Education: Broadening Citizenship Education through Global Events in China
}

Song, Gilsun*

\section{Abstract}

In China's push toward obtaining a stronger role and larger impact in the world, improving global citizenship education will become one of the most significant strategic actions in the immediate future. This paper argues that global citizenship education in China is essentially a complex process of strong national development though citizenship education. This research reports the findings of a small scale, mixed investigation into Chinese university students' perception of citizenship and global citizenship education. This study argues that the concept of global citizenship education has much more support on the individual level. The findings suggest that global events not only promote national pride but also inspire individual change and a sense of global-mindedness.

Key words: citizenship, global education, global citizenship education, globalization

* Associate professor, College of Education, Zhejiang University, China 


\section{I . Introduction}

China's economy and society have been developing dramatically and the world is watching as a new super power emerges. Having rival relations east and west for global priority over the last few decades, China has been a focal point for collaboration and contributions in our increasingly global age. Global processes and conditions continuously suggest to the world that a new educational approach for global citizenship education is needed. The swiftly rising China is moving to understand and to influence the world and it sees the importance of citizenship education as a means to national development. China is an example of how old national authority controls old citizenship modes but at the same time is pushing its citizens toward globalization. In this article, I will engage with Chinese citizenship education and its development under the context of globalization, but I will also focus on Chinese students' perceptions of these issues. I argue that old citizenship education modes need to move out into new areas. I then discuss various possibilities to develop a new approach to education and the shaping of global citizenship education.

This article is arranged in several parts; first, an exploration of citizenship, global education, and global citizenship education under the context of globalization and some possible connections between them. Second, as a case study, China is then discussed in terms of broadening citizenship education and related issues, educational focus and government educational reforms. Third, I will discuss global events held in China and Chinese students' recognition and adoption of global citizenship awareness and attitudes. In conclusion, I found that national frameworks for citizenship education are no longer adequate in the face of changing global environments and that it is necessary to build a new form of global citizenship. 


\section{П. Theoretical background}

\section{Some remarks on citizenship, global education, and global citizenship education under the context of globalization}

First, I will focus on contextual comments about globalization before moving to citizenship issues. Globalization had been debated extensively, especially, since the 1970s, and neoliberal globalization has actively transformed transnational economic processes and globalization formed from the historical combination of "Western and non-Western knowledge to produce a transnational narration of the past" (Michal Lang 2014, p. 15). Global phenomena and conditions have expanded movements of commodities, migrants, advanced science and technologies rapidly. In a brief assertion by Osler and Vincent (2002) and Wood (1999) it is stated that globalization is reality and what we are seeing and recognizing now is significant and meaningful. Globalization is clearly creating enormous mutual networks and common zones. These circumstances and their new forms and approaches are referred to as "new transnational history under globalization (Tyrell 1991, p. 1044)." Some of the most significant transitions have been an increasingly integrated world and the weakening of traditional nation state authority, and along with that an emphasis on ideas of culturally homogeneous citizenry, sharable citizen, or the global citizen (Patricia Bromley; Robertson 1992).

These ideas of global citizenship have been problematic on the national level, however, and have strongly influenced education within nations. What are the connections between citizenship and global citizenship education? Sato emphasized that the connection is global education and that global education focuses on ethical issues through liberal education (Saito Naoko 2015). In the 1990s, the global education movement started in the USA, which adopted global issue-based education; however, this has long been an act of balancing problems between citizenship education and global citizenship education. In an effort to seek balance, the USA as well as many other countries emphasized that teachers should teach global issues but should also engender patriotism in their students (Kenneth A. Tye 2003, p. 165-167). It also can be argued that in the face of global education nations may experience anger and fear concerning the scope of their citizens' identity (Patricia White 2012) so that they fall back on patriotic style teaching. Global processes, however, have been increasingly shaping global citizenship through universal individual rights and freedoms. 
The concept of global education looks toward expanding ecology, environmental sustainability, multicultural relations, peace, human rights, anti-racism, global citizenship (Kenneth A. Tye 2003, p. 166). These efforts recognize important global issues related to human rights for all through enlightenment 1 ), and provide open-minded views that move beyond national boundaries. In the 1990s, Korea, Japan, the UK, Russia and many other countries participated in UNESCO global understanding movements in an effort to strengthen international issues in their curriculums and textbooks. China (the People's Republic of China) also as a partner started global education in areas such as world history and geography, international awareness and understanding, science and humanities, and environmental awareness. In 2001, UNESCO's Associated Schools Project (ASP) was participated in by 168 countries. At present, UNESCO's Associated Schools Project (ASP) produced a global network of 10,000 education institutions in 181 countries which encouraged knowledge and understanding of world problems and cultures (www.unesco.org/education/asp).In comparison to globalization, the ultimate goal of global education is reducing economic competition and reinforcing peace and intercultural education. At this point, a nation's attitude toward their citizenship education should be recognized as shaping a global citizenship education beyond national boundaries. Understandings of global education by nation states are still an ongoing process of "patriotic" teaching as was discussed above. This will be looked at in terms of patriotism between nation and citizen from the historical perspective. Green (1997) pointed that our national education systems were created as a part of state formation in modern society. In earlier ages, citizenship is seen as a nation-based process. Aristotle as quoted by Heater $(1999$, p. 171) said, "The citizens of a state should always be educated to suit the constitution of their state." In the modern age, a core aim of fostering citizenship below the nation state specified that it goes hand in hand with the development of national civic education (Ian Davies and Alan Reid 2005). Heater (1997) explained citizenship from a legal view and showed that global citizenship is a direction starting from citizenship. She explained that citizenship is below the state level (under control of the state: e.g. national, municipal, local allegiance) and global citizenship is above the state level (world citizenship: not under the control of any state) (Heater 1997). Citizenship below the state level has been fostered to be localized, nationalized,

1) The meaning of global education is adopted from cosmopolitanism which consists of human being's fundamental needs and interests and Immanuel Kant's cosmopolitanism (Patricia Bromely 2009). 
and patriated even though we have entered a more culturally and socially homogenous age.2) Heater (1997, p. 22) also explained that global citizenship is moving from ambiguity to clarity. It is a process and its expanding ideas and its characteristics can make for a safe and peaceful world. In this way, the concept of global citizenship was clearly expressing ideas as a member of the human race, responsible for the condition of the planet, as an individual subject to moral law, and finally for the precise promotion of world government (Heater 1997, p. 36). Global citizenship is not a system of legal protections, but is more concerned with social justice, international awareness, and well-rounded citizens (Lynn Davies 2008). Therefore, concepts of global education were strongly supported to foster a global citizenship and are a natural process and condition of global trends. The contextual materials above show the connections among citizenship, global education, and global citizenship. Global education provides a possible space within citizenship that can foster global citizenship and allow the rethinking of harmony among humans.

Previously, I discussed how citizenship is connected to global education and global citizenship under the global context. In China scholarly publications adopted concepts from western literature such as global citizenship, cosmopolitan citizenship, and international citizenship but there was little difference found among them (Chen Yicang 2010; Bo Lingduo 2013, Guo Zhonghua 2010; Zhao Jun 2003). Since 2000, Chinese scholars have mainly focused on three distinct trends in discussing and understanding global citizenship education. In the first trend, scholars mainly emphasize unification (Lu Guozhi 2000; He Zengke 2002; Gu Renfu 2003; Zhou Guiying 2004; Wang Xue, Li Yu 2007; Feng Jianjun 2014). From a cosmopolitan perspective, these scholars argued that global citizenship possesses universal characteristics and moves beyond nation, race, religion, language (He Zhengke 2002). In this way, global citizenship education cultivates and requires mutual understanding, respect, liberality, common sense. These scholars were focused on living together, collaborating with and helping each other, world peace and development, and leading peaceful and safe lives (Gu Renfu 2003; Feng Jianjun 2014).

The second trend emphasizes egocentricity. Global citizenship is referred to as "Chinese global citizenship" (Deng Lei 2008). Chinese people belong in China and Chinese citizens should serve China and only then open to differences from outside (Yu Xilai 2003). These

2) The concept of citizenship is easily seen as patriotism and nationalism in the European region by Ian Davies and Alan Reid (2005). 
scholars recommend that Chinese global citizenship education should start at the university level, while basic and secondary education should focus on fostering citizenship education in the nation state. The egocentric viewpoint emphasizes that global citizenship should first be bounded by nationalism, patriotism, and cultural pride, and then through university education curricula be expanded to global understanding. This point argues that global citizenship should be a deeply state-oriented citizenship education. These scholars express the idea that a citizen will still function exclusively under their own nation state and only need be aware of the features of global citizenship while never actually becoming a global citizen.

The final trend in global citizenship in China emphasizes the coexistence of both ideas. It points out that each country's educational aims cannot be separated from common global values and are controlled by national development as citizenship education is expanded to meet global requirements (Liu Liping 2008; Zhou Hong (2008).

There are also other viewpoints, on the other hand, that the idea that global citizenship even exists in China is a fiction (Feng Jianjun 2014) and that China lacks an efficient carrier and platform for global citizenship (Zhao Jun 2003; Song Qiang 2015). However, so far citizenship education in China still largely serves the nation state, which continuously maintains overly-nationalistic pride and patriotism (Qu Xiangfei 2008; Wan Minggang 2005; Zhang Luning 2009). This view shows that China's old national identity has been maintained in its national citizenship education. On the other hand, it also means that a new form of education, shaping global citizenship education could be achieved by engaging in global education type activities.

\section{Broadening citizenship education in China}

Citizenship education in China has been strongly conceptualized and practiced in association with the ideologies of Socialism and Confucianism. During the Cultural Revolution, Chinese citizens were deprived of human rights and the freedom of education ultimately following powerful ideological collectivism and patriotism under strong nationalism. At that time, China believed that these actions were assertive decision making which would bring about national development. But it ultimately lead to the violation of human rights, a loss of direction in the education system and a recognized period of failure and shame. After the Cultural Revolution, the socio-political transformation from socialist 
nationalism to multi-level and multi-dimensional citizenship education was generating partial deregulations of society. Deng Xiaoping in 1985 spoke about the idea of world citizenship which China as a nation of the world should participate in (Wang Zhibo 1998). However, the concept of how to achieve global citizenship or its importance was not explained. The idea of global citizenship in China still focused on independent national sovereignty and national confidences (Cheng Long 2011). Deng Xiaoping's idea of global citizenship expressed a beginning of the connection between China and developed Western capitalist countries and he was anxious to keep up with advanced Western achievements. On the other hand, he was willing to open China and integrate with the rest of the world. In 2001, China proposed a multi-layered and multi-dimensional citizenship education in its basic education curriculum reform (Wing-Wah Law 2006). These reforms have adopted global education issues which inspire global attitudes and awareness and included concepts such as justice, fairness, virtuousness, international understanding (Wang Xiong 2006; Wing-Wah Law 2006).

In detail, in 2001, June 7, the Ministry of Education (MoE) in its "Outline of the New Curriculum Reform" proposed that the core of citizenship education has become an essential part and includes justice, equity, tolerance, fairness, world view, view of life, core values, social responsibility (MoE 2002) respect for international understanding and has been combined with specific courses in humanities (MoE 2001; Wang Xiong 2005). This reform was also followed by the "New Citizenship Education Textbook" in 2005 which introduced citizenship education into the basic and secondary school curriculum. In the revised curriculum after 2001, the value of individualism stresses the understanding of personal growth and development, the grasping of civic rights and responsibilities and the avocation of basic social values and morals; the local dimension focuses more on local development and social affairs; the national dimension aims at helping students understand the significance of international competition and cooperation with other countries, and the development of a global perspective and a sense of looking toward the future (Wang Xiong 2006).

China has been discussing global citizenship education which cultivates a consciousness of equal dialogue and world commonwealth beyond nation-states, race, religion, language, and which includes a tolerance of different values (Li Guozhi 2000; He Zhengke 2002; Gu Renfu 2003; Zhou Guiying 2004). The educational reform "The Outline of National Medium and Long-term Education Reform and Development Plan" in July, 2010 was more demanding of the nation state level than the global level (Cai Zhongmo 2014). Cai Zhongmo (2014) criticized 
the education reforms 3 ) three times stating that too much emphasis was placed on "qualification, responsibility, obligation" in citizenship education which is too narrow. Chinese citizenship education embraced global education but it is still at the national level of education policy reform and curriculum. While Chinese students learn global education as a method of promoting patriotism; however, this is also a way to interact with global processes. If China wants to be a global power, it needs to reconsider its citizenship education. Chinese citizenship education emphasizes understanding global competition and cooperation and global views for the development of their own nation and to broaden the concept of Chinese citizenship, but this view still maintains the below the nation level citizenship education.

\section{Shaping citizenship education through global events in China}

As David Black and Janis Van Der Westhuizen (2004) pointed out, global events and activities can promote national building in four aspects: democratic polity, economic development, identity building and global influence. At the same time, people can recognize and appreciate other countries' cultures and societies. They showed clearly that global events bring mutual understanding to citizens who can in turn inspire pride in their own country and respect for others. Governments, as members of global society, need to cultivate well-qualified citizens who are willing to welcome and respect foreign friends and guests. In this respect holding global events presents significant opportunities in opening to the world. For instance, the Shanghai Expo (World Exposition), Shanghai in 2010 and the Olympic Games, Beijing in 2008 held by China brought great performances to the world and also upgraded Chinese citizen's civil awareness to a global level. These global events in China presented incredible scientific and technological inventions or extreme physical abilities to the world. Through these types of large-scale global events, many governments recognized that citizenship education should be broadened through global education. Chinese students through participation in these global events have been establishing the foundation of the

3) In 1985 “CPC central committee decision on reform of the education system (中共中央關于敉育体制改革 的決定)” used the term “National Education (國民敎育)." In 2010 “The Outline of National medium and long-term education reform and development plan outline (國家中長期敉育改革与發展規划綱要2010-2020)” used the term“Citizen (公民)." 
global-minded citizen making China global. These global events and activities not only focused on China's own national pride and patriotism, but also brought about an awareness of harmony with others. China recognized that citizenship education should extend knowledge, skills, and attitudes to the global level (Man Mingang 2005; Zhang Luning 2009).

In hosting the global events, for instance the Shanghai Expo, China began training on three levels: government, schools and organizations, and the individual. The government provided education in volunteer incentive planning, leadership for global events and activities, cultural displays, creativity action plans, domestic and international advertising (Shanghai City Education Committee, 2010). The school level provided courses on related global knowledge, attitudes, and actions for communicating with international friends and guests (Hu Yahui, Lu Zhiwen 2010). Volunteer education and training were provided by governments and schools in areas such as role recognition, service skills, multi-cultural communication and attitudes, generosity and morality, and emergency skills (Zhou Kai, Wang Huijie 2010; MoE 2010). The three different levels promoted their individual operations for the global event. The Shanghai Expo brought out viewing Shanghai as a real cosmopolitan city (Huang Jianhai 2010) but it also reinforced national pride and patriotism on the below the nation level (Wan Mingang 2005; Zhang Luming 2009).

\section{Research Design}

\section{Participants}

This study uses mixed method quantitative and qualitative research methods through a series of surveys and semi-structured interviews. The design is a multi-layered citizen recognition framework (from Wing-Wah Law 2010; Turner 2001; Preston 1997) for the survey. The analytical method for interviews was adopted from a social constructionist perspective (Berger \& Luckman 1966) in order to understand individual (or people's) ideas and beliefs (Marshall and Rossman 2006). The mixed research in this study is necessary to understand the recognition and attitudes of Chinese citizenship which brings Maxwell's relatively solid reliability and validation (Maxwell 2005).

This research is designed is to understand how students (individual perspective) recognize 
global citizenship and their beliefs and thoughts about it through experiences in global events. Students participating in this research data include various volunteers with experiences especially in the Olympic Games, the Shanghai Expo, and other regional activities. The choice of these students is not to focus on one certain global event experience, but rather to choose students who have rich experiences with global events and activities. Therefore, my data consists of student volunteers not only from the Shanghai Expo but also other global events. Based on this, the three research questions are designed to observe their beliefs about citizenship and global citizenship education. These questions are also used to investigate how students recognize their own perspectives and their own understandings of their own country and future.

RQ1. How do you understand the concepts of citizenship and global citizenship?

RQ2. What are the roles or characteristics of global citizenship?

RQ3. What factors of global citizenship education are forming in China? Why? Do you think there are any conflicts?

Survey sampling was collected from 200 undergraduate students in 2014 (100 volunteers in global events and 100 non-volunteers); 174 efficient surveys were returned with a valid survey rate of $86.5 \%$. The Survey consists of undergraduate students' basic background, recognition of skills and attitudes on the global, national, local, and individual levels (See Table 1).

Interview sampling consisted of 20 interviews conducted from September to December, 2015 and 5 interviews done at the same time as the Survey in 2014. Twenty-five students were selected for 20-30 minute interviews (10 from Shanghai, 10 from Hangzhou, 2 from Beijing, and 3 from other areas; 10 from 3rd year undergraduate students and 10 from 4th year students; and five being from all years) in universities as Zhejiang University who had volunteer experiences in global events such as the Shanghai Expo, the Olympic Games, and other global activities.

The limitations of this research are as follows: first, there are no strong representative targeted wider schools and populations with confidence. Second, it avoided talking about sensitive issues such as human rights, freedom, and relative political issues. Third, interview respondents' were weighted too much toward senior years (3rd and 4th years). 


\section{Data results}

Data analysis was presented under one big umbrella with 3 research questions. First I begin with an analysis of the overall aim and survey results and then go on to discuss the three research questions by briefly analyzing students' recognition and attitudes.

\section{Survey results}

The survey consisted of 49.1 males and 50.9 females, 26\% local Shanghai students and $74 \%$ non-Shanghai students in universities; $40.5 \%$ were volunteers for global event activities (especially the Shanghai Expo), 59.5\% non-volunteers for activities (See Table 1).

Overall, the data results show that global events promote global citizenship education on the individual level (Mean 3.49), the local level (Mean 3.15), the national level (Mean 3.27), and the global level (Mean 3.15). It is very interesting the most highly marked score is the individual level which has an average much higher than other levels (See Table 1). Students from universities in Shanghai and volunteers on the individual level showed Mean 4.15 and Mean 4.12 respectively and these means are much higher than students from other universities. 


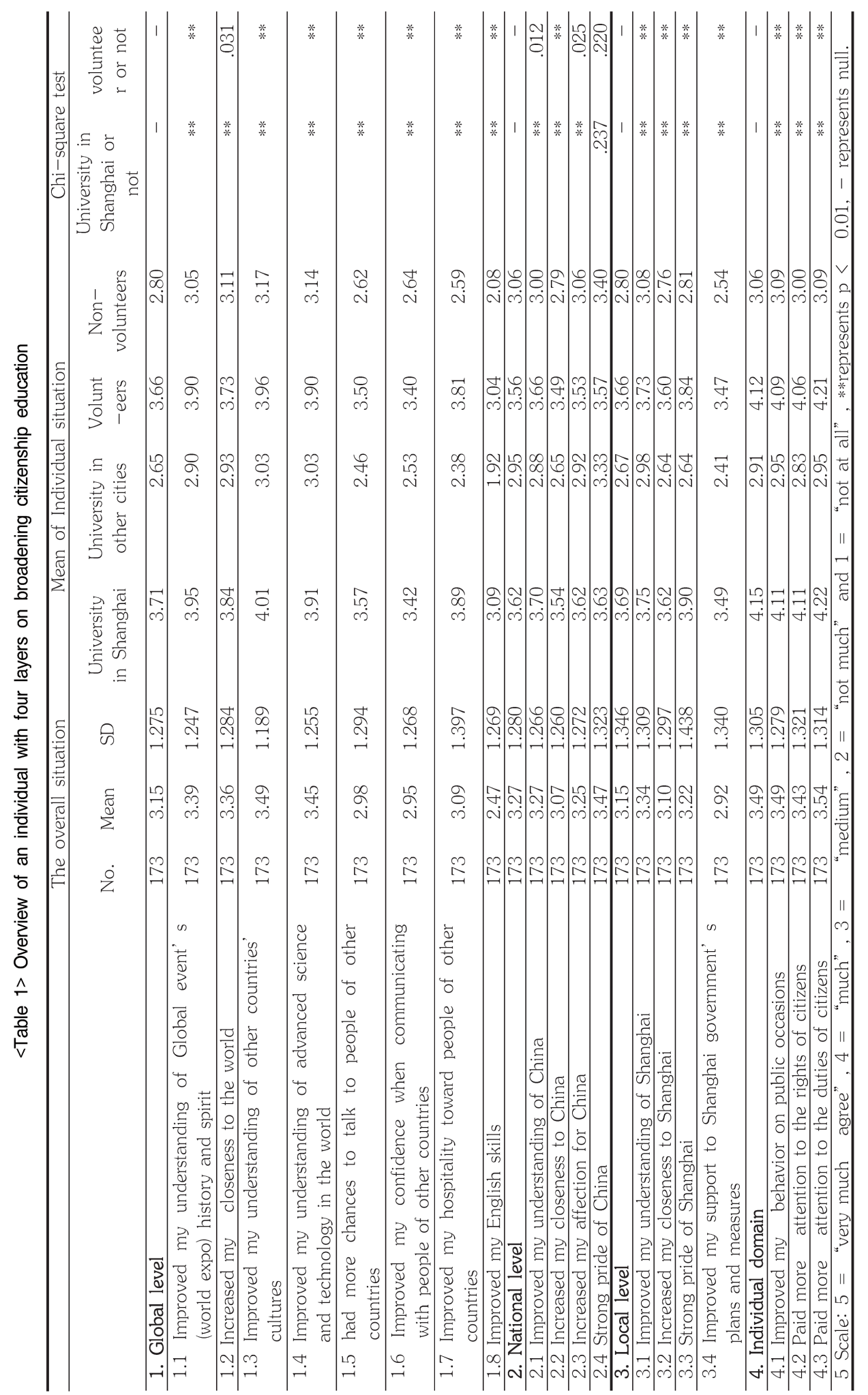




\section{1) Expanding global citizenship education}

The global events affected students' knowledge, skills toward global education development thereby closing the distance between students and global society. With 5 being "very much agree," 4 "much agree," 3 "agree," 2 "not much agree," and 1 "not agree at all," the survey marked that students "1.3 Improved my understanding of other countries cultures (Mean: 3.49)" and "1.4 improved my understanding of advanced science and technology in the world (Mean: 3.45)." These two questions were responded to on the relatively high positive level by students from university in Shanghai (Mean 3.91 and Mean 4.01) and volunteers (Mean 3.96). Survey question "1.1 improved my understanding of global event's history and spirit" was also very highly responded to by students from university in Shanghai (Mean 3.95) and volunteers (Mean 3.90). Whereas students from other cities had relatively lower means than other students, the question on "improved my understanding of advanced science and technology in the world (Mean 3.03)" were higher than the rest of the questions on the global level. This shows that education for the global events closed the link between students and global citizenship concepts, enhancing acceptance and attitudes of generosity. Training courses for global events affected students' positive behaviors in their volunteer activities (Zhou Kai, Wang Huijie 2010). The words of one 3rd year undergraduate student (female, volunteer, Shanghai) add more support:

"I took courses provided by our university on communication skills and attitudes and various information about the Expo history... Through the Shanghai Expo volunteer experience I realized foreign country's civilization and it gave me a broader world view $\cdots$ I learned from them. I was surprised how great the world was and that we have to grow with each other and need more mutual understanding. These achievements were great contributions to our world and I would like to learn more."

2) The national level

Students expressed that they recognized their own country's development with great pride; improved my understanding of China (Mean 3.27), closeness to China (3.07), and strong pride in China (Mean 3.47) scored higher than "increased my closeness to China (mean 3.07). Hosting the global events, as Black, David and Janis van der Westhuizen (2004) mentioned 
promotes national building for democratic polity, economic development, identity building and global influence and most respondents emphasized their national pride and respect for being a citizen of China (Wan Minggang 2005; Zhang Luning 2009). All interviewed students expressed similar comments as the respondent below:

"The Chinese Pavilion made foreign visitors deeply understand ancient Chinese civilization which built precious heritage and excellent achievements of advanced technology $\cdots$. It made me proud of our position and role among world civilization."

(2rd year undergraduate student, male, Hangzhou, 2014)

Another respondent put the case even more strongly and emphasized his sense of citizenship:

"My volunteer work is very important because my behavior and knowledge can directly influence our country's reputation. I am a Chinese; I do not want to lose face for my country."

(3rd undergraduate student, male, other city)

\section{3) The local level}

On the local level, students in Shanghai showed a stronger recognition and sense of belonging than on the global and national level (See Table 1. Local level questions for 3.1, 3.2, and 3.3). They are very proud of Shanghai (e.g. Shanghai people) and proud at successfully holding the Expo (mean 3.9). On questions about the local level, students from Shanghai, Hangzhou, and Beijing (developed cities) emphasized a strong sense of pride for the place which they were born as is described by one respondent below:

"I was born in Shanghai. It was the earliest in modernization, internationalization, and humanization, and is full of vitality and energy as a big cosmopolitan city $\cdots$ I do not want to leave Shanghai. I want to be part of this city."

(3rd year undergraduate student, female, Shanghai)

4) The individual level

Through all the levels in the survey, students at the individual level showed the highest 
scores on "improved their behaviors on public occasions (Mean 3.49)", "more attention to the rights of citizens (Mean 3.43) and the duties of citizens (Mean 3.54)." The most important point is that the students at universities in Shanghai and volunteers very much agreed about their behavior improvement, recognition of rights and duties as a citizen (Mean of above 4.0). Global events help and inspire individual development and strengthen ideas about global citizenship for their future. One student commented as below:

"...I've participated in a lot of global events and activities. I know how to communicate with foreign guests, make foreign friends $\cdots$. They are friendly and interested in my learning and working. I learn about helping with their problems, understanding their cultural differences, respecting their privacy, etc. I want to open my view to the world."

(3rd year undergraduate student, male, other city)

A majority of respondents emphasized the individual desire and demand for their own development and the need to have experiences outside of their own country. Through the global events and volunteer work the students were inspired greatly by other countries and by listening to new, exciting news. Such communicated knowledge was echoed and provided opportunities for a sense of global citizenship as one respondent commented below:

"I guess I gained many global experiences through volunteer works. Someday I would like to study abroad in the USA and get a master and doctoral degree. My working should be global, in the UN or other international organizations... I want to be a prepared global citizen because I have to work for the world beyond China." (4th year undergraduate student, male, Hangzhou)

Through the survey results, students on the global, national, local, and individual levels had the highest scores in volunteers at universities in Shanghai. The individual and local levels also showed higher scores than the national and global levels. Concerning the 4 levels, respondents generally supported the 4 levels but when they talked about individual aspiration their voices grew louder and more excited. The survey and interviews provide the general sense that global events bring a sense of citizenship and global-mindedness but also promote pride in their own culture at below the nation level. On the other hand, the data also shows the inspiration of respondents to make changes in their views and behaviors on a more global level. Citizenship education in China is still focused on nationalism and pride, 
but as is shown through the data, students want more global citizenship education which will support them on the nation and local levels as well as in their personal development. The global events provided not only national pride and feelings of nationalism but on the global and individual levels it also highly emphasized the importance of global citizenship education.

After discussing the survey results, I will move to a discussion of the three research questions, RQ1, RQ2, and RQ3.

Table 2 lists the students' responses to the concepts of citizenship and global citizenship. The table lists the most common descriptions for each category. The two lists are not mutually interrelated and, to some extent, show different understandings of national citizenship and global citizenship, yet they also partly overlap on some of the characteristics.

<Table 2> RQ1: The nature of global citizenship and citizenship

\begin{tabular}{lll}
\hline \multicolumn{1}{c}{ Citizenship discourse } & \multicolumn{1}{c}{ Global citizenship discourse } \\
\hline & Pride & World recognition \\
& Responsibilities & Opening (multi-dimension) \\
& Duties & humanity \\
& Belonging & Lack of duties \\
& Chinese \& foreigner & World activities \\
Understanding & Legal & International organizations \\
& Politics & Foreign languages \\
& National image & Various cultural recognition \\
& Privileges & No system and legal protection \\
& Nation (Communist) & Ideal \\
& Our culture & Broad \\
& Narrow & Global recognition \\
Peace, Respect, Generous & Objective mind \\
Moral & Fair relation \\
Harmonizing & Peace, respect, embrace \\
Fair & Self-competencies \\
Optimistic attitude & Agree disagrees \\
Communication & Contribution \\
Contribution &
\end{tabular}

In the words of one respondent (4th year, female, Hangzhou):

"My definition of citizenship and global citizenship is based on rights and responsibilities. Citizenship is where I belong and I have to serve my country and my country protects me. I am not sure about the meaning of global citizenship, but I think it is ideal and paying attention to 
global issues and humanity."

When considering Table 2 and the students' interviews, it can be seen that the students understand that the two concepts are different; however, when asked about the characteristics of the two concepts, students explained them in very similar ways. While the students seemed to be confident in their understandings and views of national citizenship, they did not seem so confident concerning global citizenship. In the words of on student (3rd year, female, Shanghai):

“...I think both concepts are correlated. Isn't global citizenship a bigger view so it includes citizenship? -..Being a global citizen has broader characteristics such as peace, fairness, embracing our planet. Well, citizenship education from what I learned is also about becoming a good person, helping, morality, ‥harmonizing our society. I think they are closely related."

Most of the respondents placed considerable emphasis on the differences between both concepts but also agreed that they are not exclusive and mutually connected. Concerning the roles of global citizenship, students also expressed common relations between them.

$<$ Table 3> RQ2: What are the roles or characteristics of global citizenship?

\begin{tabular}{cll}
\hline & \multicolumn{1}{c}{ Roles discourse } & \multicolumn{1}{c}{ Characteristics } \\
\hline & Not clear & Multi-culture and society \\
& Philanthropism & Communication \\
Students' & Abilities and competencies & Languages \\
ideas & Individual values & Universal ethic principles \\
and beliefs & Global problems & Integration \\
& Sustainable development & Self-reliance \\
& Neutrality & Highly educated professions \\
& Global benefits & Flexible mobility \\
\hline
\end{tabular}

Table 3 expresses students' ideas about the roles and characteristics of global citizenship. The roles of global citizenship discourse are seen as important in terms of highly qualified and broad views emphasizing self-reliance and individual development (Cogan 2000; Banks 2004; Wang Xiao 2005). One student commented as follows:

\footnotetext{
"...Citizenship is entitled when you were born, but global citizen is obtained by your own
} 
will. Global citizens are willing to open to the world and try to contribute."

(3rd year, female, Beijing)

Generally, the recognition of the roles of global citizenship were positive and expressed an attitude of mutual development and contributions to global society. Respondents also largely agreed that the role of global citizenship needs to be broadened in China. This recognition of global citizenship was also directly connected to personal development and future careers. One student responded as follows:

"I think [global citizenship] is something each citizen can have $\cdots$ If I work in a global organization and am evaluated as a good worker who contributes to a global society, ' aren't I a global citizen even though I am a Chinese?Contributing to global citizenship is also contributing to my own country." (4th year, female, Hangzhou)

However, some respondents also explained that the roles of global citizenship are very difficult to measure. For example one respondent (4th year, female, Shanghai) said:

"...I am not sure what a global citizen's role is. There are no systematic principles or awards. Based on their own knowledge and principles they make decisions about what they do $\cdots$ They may not be neutral, they definitely have their own citizenship identity. How much can they hold a neutral position?"

Students seem to be unclear about global citizenship roles; however, they are supportive and express positive attitudes where global citizenship brings trust, belief, relationships (Turner 2001) and reconsidered importance of global roles. Research question three concerns the development of global citizenship education in China and seeks to understand students' ideas about any conflicts that might arise from it.

RQ3. What factors of global citizenship education are forming in China? Why? Do you think there are any conflicts?

An overall analysis of the recognition of the respondents is shown through negative and positive comments. First, the concept of citizenship also has negative overtones with the 
potential for conflicts in their roles. For instance, when discussing political issues and ideas of national loyalty attitudes of the respondents largely expressed negative overtones. One respondent said:

"I think the biggest conflict between the both relations is being loyal and faithful to my country. There might be situations where global activities are related to sensitive political issue s.. From my perspective, ". no matter what I should make a decision as a citizen. I mean my ultimate decision is as a citizen unless it is no problem from the perspective of a global citizen." (3rd year, female, Beijing)

For others, global citizenship can expand motivation from belief in the needs of the wider society and in developing common values. On the subject of positive attitude a 4 th year respondent commented:

“...Global citizenship consists of all people's awareness, respect for each other, not being selfish, having moral behaviors...I am expected as a citizen to respect the diversity of the world and morality and reinforce the idea of global citizenship.." (4th year, female, other city)

\section{Discussion and Conclusion}

Reflecting on what has been learned from the respondents' answers to the three research questions, the views of understanding citizenship and global citizenship showed earlier findings about tension and struggles (Heater 1997) but forming inter-connections and sharable agenda (Griffiths 1998; Grad delanty 2000) through roles and knowledge. The study also underlines the complexity and diversity in global citizenship and citizenship education recognized in different approaches partly reflecting data in this study. Most countries still lack diversity and the intention of global citizenship education. In China citizenship education is still focused on serving the nation. However, Chinese curriculum reforms and samples for this topic found that global citizenship education is developing as students are looking to improve and develop their own lives. This is also one of the results of the global events. From this it can be seen that the development of global citizenship is not under the control of the state but rather is an evolution formed from connections with the rest of the wide 
world.

In answer to the overall research question, the first key point was that Chinese students think China is not ready for global citizenship education, but they think China should start because China's citizenship education focuses on the below the nation level (Wing-Wah Law 2006). The data analysis found that students had an increased sense of pride and patriotism, and a reduced feeling of China's negative image from outside. The concepts of global citizenship education and participation in the global events and the education they received from volunteering at these events makes them feel more connected on the global level and gives them the ability to recognize what they want to learn and do for their own career development. Secondly, volunteers and also the students born in Shanghai were seen as well integrated and open to the world. There was a coexisting and mutual interaction between the two concepts of human rights and responsibilities (Turner 2001; Preston 1997) on the individual level, especially for volunteers. A notable point was that holding global events and activities emphasized the strengthening of national pride and nationalism (Wan Minggang 2005; Zhang Luming 2009; David Back and Janis Van Der Westhuizen 2004) but also promoted global citizenship and its characteristics.

In answer to RQ1, students' perception of the two concepts were distinguished by particular vocabulary groups and clearly defined and limited by legal definitions on the below the nation level (Heater 1997). Based on the vocabulary used by students, it can be seen that they think that the definitions of the two concepts are different; however, when describing the two concepts, they use very similar words. Nevertheless, overall the data and understanding and characteristics of global citizenship are highly connected. Answers to RQ2 also expressed ideas that the role of global citizenship should be broadened in China as contributions to the world in terms of skills and knowledge are very sharable. The respondents' comments on the RQ2 clearly supported global citizenship in terms of common virtues and moral behaviors. From this point, respondents emotionally aspire to global citizenship which promotes images of professional, capable citizens who are able to view the world and global issues from a neutral position. Students expressed that they are very willing to accept the characteristics of global citizenship that they discussed on their surveys and in their interviews. Regarding the tension and conflicts that may come along with global citizenship in RQ3, the findings suggest that the discourse on global citizenship should not be conducted concerning sensitive political issues. This research suggests that global 
citizenship education in their career development is highly accepted as positive, yet sensitive political issues do not fall under the realm of global citizenship and in that sense students would see themselves as Chinese citizens.

Through global events and activities China promotes national pride and nationalism. The global events highlighted China's ascendance in diverse ways but through the events China also made itself available to foreign people from all over the world. While China was on display at these events, it also experienced and recognized other nations of the world. Through contextual materials it can be seen that global citizenship is not controlled by a state; a global education for global citizenship is naturally produced and brings about a stable space for all who value tolerance and mutual understanding and expect morality and generosity among countries. Global citizenship education is not defined by one state, but all nations working together on global problems and common issues. Minimizing wars and conflicts, preventing disasters and the destruction of the environment are all common global issues and should be solved together. Once again, global citizenship is not a new or ambiguous concept - it is a concept based on universal human rights, freedom and the responsibilities that come along with it. 
References

Back, David R. and Janis van der Westhuizen (2004). The Allure of global game for 'semi-peripheral' polities and spaces. A research agenda, third World Quarterly, 7, 1195-1214.

Berger, P. L. \& Tomas Luckman, T. (1967). The social construction of Reality; A treatise in the sociology of knowledge Harmonsworth, Penjuin Books, p.249.

PenguinBo Lingduo (2013). Graduate students' international experience and global citizenship (研究 生的跨国体验及其全球公民身份发展). Huadong Normal University Press, China.

Cai Zhongmo (2014). Globalization of Chinese higher education: Current situation, problems and strategy(中国高等教育全球化的现状 、问题与对策). 现代教育管理, 1, available at http://www.docin.com/p-1201475100.html.

Cogan, John J. (2000). Citizenship education for the twenty-first century: Setting the context. In John J. Cogan and Ray Derricott (Ed.), Citizenship for the 21st century -An international perspective on education (p.1-23), Routledge.

Chen Yizang. (2010). The raising and development of global citizenship education ideological trends (全球公民教育思潮的兴起与发展). 外国教育研究，3，65-69.

Cheng Long. (2011). Deng Xiaoping's world citizen ideology(邓小平的“世界公民”思想). 领导文 萃, $15,34-37$.

Deng Lei. (2008). Research on cultural Selection: World citizenship ectucation curriculum in Chinese universities (中国大学世界公民培养课程之文化选择研究). 西南大学出版社.

Feng Jianjun. (2014). Global citizen society and global citizen education(全球公民社会与全球公 民教育). 高等教育研究，3，6-14.

Gu Renfu. (2003). New curriculum of moral education: Guiding students to understand the world and other people-World citizen education (德育新课题: 引导学生了解世界了解 他人兼谈世界公民教育)。上海师范大学学报(哲学社会科学.教育版)，4，1-5.

Gu Tanwu (1970). Daily understanding roll 17 (日知录；卷十七，原抄本). 台北：明伦出版社. Guo Zhonghua. (2010). The Construction of multi-citizenship system under the context of globalization (全球化背景下多元公民身份体系的建构). 武汉大学学报(哲学社会科学版)， 1, 84-89.

Griffiths, R. (1988). Education citizenship and independent learning. Jessica Kingsley. 
Heater, D. (1997). The reality of multiple citizenship. p.36 in I. Davies and A. Sobisch (Eds.), Developing European citizens. Sheffield Hallam University Press.

Heater, D. (1999). What is citizenship? Cambridge, UK: Polity Press.

He Zengke. (2002). Introduction to global citizen society (全球公民社会引论). 马克思主义与现 实, 3, 31-40.

$\mathrm{Hu}$ Yanhui and Lu Zhiwen (2010). A Lesson for the 2010 Shanghai expo. available at http://www.xhedu.sh.cn/cms/data/html/doc/2010-05/21/225951.

Huang Yu (2003). Development and direction of Chinese environmental education (中国环境 教育的发展与方向)，环境教育，2，8-16.

Ian Davi,es and Alan Reid (2005). Globalising citizenship education? A Critique of global education and citizenship education. British Journal of Education Studies, 53(1), 66-89.

Kaplan, S. (2006). The Pedagogical state. Education and the politics of national culture in Pass-1980 Turkey. Stanford: Stanford University Press.

Lynn Davies (2008). Global citizenship education, Encyclopedia of peace education, Columbia University, available at http://www.tc.edu/centers/epe/

Lu Guozhi. (2000). Rudderless and the world citizen's mental state: Talking about construction of the concept in Chinese comparative literature (群龙无首与世界公民的 心态一一试论中国比较文学的观念建构). 东岳论丛, 2, 125-129.

Maxwell, J.A. (2005). Qualitative research design: An interactive approach (2nd Ed.). Thousand Oaks, CA: Sage.

MoE (2001). Outline of basic education curriculum (基础教育课程呢改革纲要, 试行, 第一章第一

条), available at http://www.annian.net/show.aspx?id=2310\&cid=19.

MoE (2002). 4th article in the 16th Chapter (第16章第4条), available at

http:/ /www.annian.net/show.aspx?id=2310\&cid=19.

MoE (2010). Promoting student volunteer service guidance, available at http//news.xinhuanet.com/edu/2009-07/14/content_11705033.

Marshall, C. and Rossman, G. B. (2006). Designing Qualitative Research (4th ed.). Thousand Oaks, CA: Sage.

Michael Lang (2014). Histories of Globalization(s). In Prasenjit Duara, Viren Murthy, and Andrew Sartori (Ed.). A Companion to global historical thought (pp.399-411), Wiley Blackwell.

Osler, A. And Vincent, K. (2002). Review. Citizenship and the challenge of global education, Stoke On-Trent, UK and Sterling. VA: Trentham). 
Patrica Bromley. (2009). Cosmopolitanism in civic education: Exploring cross-national trends, 197 2008. Current Issues in Comparative Education, 12(1), 33-44.

Patricia White (2012) Making Political anger Possible: A task for civic education. Journal of Philosophy of Education, 46(1), 1-13.

Preston, P. W. (1997). Political/Cultural Identity: Citizens and nations in a global era. London: Sage.

Qu Xiangfei. (2008). People, citizen, World citizen: Evolution of human rights and the system guarantee of human rights (人·公民·世界公民: 人权主体的流变与人权的制度保障). 政 法论坛, 4, 18-30.

Saito Naoko (2015). Philosophy as translation and understanding other cultures: Becoming a global citizen through higher education. Educational Studies in Japan: International Yearbook, 9, 17-26.

Song Qiang (2015). Who is giving us 'World citizen' qualification? - Refection on World citizenship education reasonability (谁来赋予我们“世界公民”资格?一一世界公民教育的 合理性反思. 外国教育研究, 3, 21-31.

Tyrell, I. (1991). American exceptionalism and an age of international history. American Historical Review, 96(4), 1031-1055.

UNESCO. (1997). UNESCO Regional conference on human rights education in Europe (Paris, UNESC), available at http://unesdoc.unesco.org/images/0011/001102/110218eo.pdf. Wan Minggang. (2005). Global education and World citizenship education under the multicultural background (多元文化背景中的全球教育与世界公民培养). 西北师大学报 (社会科学版)，6，99-100.

Wang Xiong. (2006). A new beginning and exploration in Citizenship education: the opportunities and challenges of Chinese citizenship education in the 21st century (公民教育新的起点与探 索:21世纪中国公民教育的机遇与挑战). Zhengzhou University Press.

Wang Xue and Li Yu (2007). Primary investigation into World citizenship education (世界公民 培养问题初探). 赤峰学院学报(汉文哲学社会科学版), 1, 55-56.

Wang Zhibo. (1998). Open World and World citizen - Deng Xiaoping's two concepts (开放的 世界与世界公民一一邓小平开放观的两个概念. 福建论坛(文史哲版)，3，12-13.

Wen Liping. (2008). World citizen: New aim of Chinese education (世界公民: 中国教育培养目 标的新取向. 边疆经济与文化, 5, 74-75.

Wing-Wah Law. (2004). Globalization and citizenship education in Hong Kong and Taiwan. Comparative Education Review, 48(3), 253-273. 
Wing-Wah Law. (2010). The state, Citizenship education, and international events in a global age: The 2008 Beijing Olympic Games. Comparative Education Review, 54(3), 343-367.

Wing-Wah Law (2006). Citizenship, citizenship education, and the state in China in a global age. Cambridge Journal of Education, 36(4), 597-628.

Yu Xilai. (2003). Chinese human oriented world citizenship (中国人本位的世界公民主义). 战略 与管理, 2, 28-34.

Zhang Luning. (2009). Idea of world citizen and world citizenship education (世界公民观念与 世界公民教育). 思想理论教育, 20，25-28.

Zhao Hui. (2003). Study of world citizenship education theories (当代世界公民教育的理念考 察). 外国教育研究，9，25-30.

Zhou Hong. (2008). Fostering World citizen's cultural tolerance and self-confidence (论培养世 界公民的 文化包容与自信品格). 大学教育科学, 6, 11-16.

Zhao Qing Jie and Liu Shu Hui. (2009). Ideas of citizenship and the theme of citizenship education (公民的理念与公民教育的主题). 新视野, 3, 89-90.

Zhou Han Min (2010). The Shanghai Expo: A precious chance to improve national soft power (上海世博会 : 提升国家软实体的南风机遇). 中国政协, 5, 21-21.

Zhu Li Ling. (2009). Volunteer Service: New approach of citizenship education in youth (志愿服务：青少年公民教育的新途径). 北京青年政治学院学报，18,(2)，8-14.

* Received January 1, 2016 / Revised March 20, 2016 / Accepted April 30, 2016

* Song, Gilsun: associate professor, College of Education, Zhejiang University, China

* E-mail: gilsunsong@zju.edu.cn 